By a special method Dr. Scripture plots a melody curve from a transcribed record, showing, for example, the curve when "Oh" is uttered "sorrowfully," or " admiringly," or " questioningly," \&c. He worlss out the "melody curves" in Depew's speech, and then writes the melody in musical notation. With regard to the emphasis of speech as indicating the emotional condition of the speaker's mind, we must, however, take into account not only melody, or the sequence of tones of different pitch, but also the intensity, the passing from diminuendo to crescendo, or vice versa. Dr. Scripture has not attributed sufficient importance to this element in the analysis. The amplitudes of the wave forms increase or diminish according to the intensity.

Dr. Scripture expounds the principles of harmonic and inharmonic analysis in two chapters at great length and with much clearness. Nowhere have I met with a fuller exposition of Fourier's theorem and its application to acoustical problems. He does not hold, however, that a vowel curve is produced by combining simple sinusoid vibrations in a harmonic series, and he concludes that

" the sounds from the musical instruments are presumably produced in this way, but we dare not assume that the vowels are so produced until the fact has been proven" (p. 78 ).

He shows how to separate, by the rules of Hermann, harmonic and inharmonic sinusoids from the mixed results of a harmonic analysis. How is one vowel distinguished from another? Are the differences due to the presence of certain tones of definite pitch, as held by both Helmholtz and Hermann? If so, are we to hold with Helmholtz that these tones are harmonic overtones of the glottal tone or that they are inharmonic to it, as stated by Hermann? Dr. Scripture holds that Hermann has completely disproved the theory of Helmholtz. After discussing the method of analysis with frictional sinusoids, as distinguished from simple sinusoids, he states:-

"The vibrations of the voice in speech are ... composed exclusively of frictional sinusoids and not of simple sinusoids, as has hitherto been assumed. Can a method of analysis into frictional sinusoids be found? Does an analysis into simple sinusoids give false results for the vowel curves?" (p. ror).

He answers the question thus :-

"The treatment of the curves by simple harmonic analysis - the only method that has hitherto been triedfurnishes results that are so wrong as to be utterly misleading when used to indicate the manner in which the vibrations were produced."

I observe that Dr. Scripture states that Prof. Weber, of the Swiss Polytechnicum, along with Schneebeli, was the first to apply the Fourierian analysis to a vowel curve, but he does not give the date when this was done. We must not forget that such an analysis was made by Fleeming Jenkin and Ewing in 1878 " On the Harmonic Analysis of certain Vowel Sounds," Trans. Roy. Soc. Edin., vol. xxviii., p. 745).

As to the mode of production of vowel tones, Dr. Scripture discards the views of Wheatstone, Grassmann, and Helmholtz that the glottal lips vibrate after the manner of strings or the borders of a membrane on each side of a narrow opening, and he fully adopts the "puff" theory of Willis and Hermann, according to which

"the glottis emits a series of more or less sharp puffs; each puff, striking a vocal cavity, produces a vibration whose period is that of the cavity; a single wave-group shows the sum of these vibrations from all the cavities; the periods of these vibrations may stand in any relation to the interval at which the puffs come, that is, to the fundamental."

NO. I 947 , VOL. 75$]$
There can be little doubt that, at all events in his later days, Helmholtz saw the analogy between the action of the glottis and the "puffing" sounds of a syren, but he undoubtedly held that the overtones were harmonics of the glottal tone. Hermann, however, has conclusively shown that at least some of the tones of the cavities may be irharmonic to the glottal tone, and Dr. Scripture supports this view by many ingenious experiments. His description, however, of the glottis is not either anatomically or physiologically quite satisfactory. It is not in accordance with anatomical detail to write, "Each glottal lip consists mainly of a mass of muscle supported at the ends and along the lateral side," or that "the two masses of muscle close the air passage," or that the air from the trachea "bursts the muscles apart." The glottis is a much more delicate structure than these words would imply. It contains much elastic tissue at the borders which come together, according to the "puff" theory, and the muscular structures are devoted to placing strains on this tissue and to separating or approximating the lips of the glottis. Dr. Scripture's view is that

" the effect of each puff on each element of the vocal cavity is double: first, to arouse in it a vibration of a period depending on the cavity; second, to force on it a vibration of the same period as that of the set of puffs."

The glottal puff produces a frictional sinusoid with large amplitude and a very large coefficient of friction, and the cavity vibrations are also of the frictional sinusoid form. This may explain the failure of a simple harmonic analysis to reveal the real elements of the vowel curve.

In chapter ix. Dr. Scripture gives his views as to the action of the organ of Corti in relation to wave analysis, and he conjectures that portions of it are affected by "groups of stimuli," when complex wave forms reach it. This does not seem very conclusive, and in my judgment the theory of Helmholtz, by which he explained the action of the organ by adopting the principle of resonance, still holds the field.

Dr. Scripture has also attempted a synthesis of vibrations by ingenious mechanisms, by which he obtained curves somewhat similar to speech curves. There is no doubt a great future for this line of experimental research. After fully worked out examples of vowel analysis, with all arithmetical details, Dr. Scripture appends to the end of the monograph a number of elaborate schedules to assist in the Fourierian analysis, namely, schedules of $\mathrm{I} 2$ ordinates, 24 ordinates, 36 ordinates, and $7^{2}$ ordinates. The preparation of these schedules was a very laborious task, and the work will be much appreciated.

We congratulate Dr. Scripture on the production of a splendid monograph. It might have been improved by fuller bibliographical details, and perhaps by a more adequate recognition of the work of others. JOHN G. MCKENDRICK.

\section{AGRICULTURAL EDUCATION AND} RESEARCH.1

NE of the functions of the Board of Agriculture is the administration of a Treasury grant for the purposes of agricultural education, and though the total distributed is not large it has been a potent factor in stimulating the development of the higher forms of agricultural education during the last fifteen years. It is certain that many of the county councils

1 The Annual Report of the Board of Agriculture and Fisheries on the Distribution of Grants for Agricultural Education and Research in the
Year $1905-6$. 
which now help to maintain colleges giving instruction of a university standard would have never started at all or would have rested content with something in the nature of a farm school had it not been for the advice and practical encouragement provided by the Board of Agriculture.

During the past year we see that seven institutions were in receipt of an annual grant of 1oool., 200l. of which was in respect of the farm maintained by the college, while twelve other institutions received sums ranging from $800 l$. down to rool. The University College of North Wales at Bangor and the Armstrong College at Newcastle each received a further $25 \mathrm{ol}$. for instruction in forestry. It is noticeable that the Board seems to make the amount of its grant depend upon the type of education given, not taking into account the number of the students educated or the extent of local support. Thus Wye College, the total expenditure of which is set at $17,414 l$. , receives the same grant, Ioool., as other colleges the total expenditure of which does not reach 3000 . Probably this policy is most adapted to the pioneer work, when it is all important to get the colleges started, but the time is drawing near when some of the colleges supported most liberally by their localities must feel that they should be treated on the principle of the Treasury grants to university colleges, which are given roughly in proportion to the local support received.

In the body of the report nearly all the collegiate centres have the same tale to tell of an increase in the number of students, and that greater use is being made of the college by the farmers in the district. It is not too much to say that the attitude of the general body of farmers towards scientific work has entirely changed during the last ten or twelve years, wherever they have been within the range of influence of one of these permanent centres of instruction. The supply of agricultural intelligence certainly preceded the demand, but now the demand has more than grown up to the supoly.

The second part of the present year's report deals with the expenditure of the various county councils on agricultural education of various kinds out of the funds they derive from the "whisky money." From this we learn that in $1905^{-6}$ the counties of England and Wales expended very nearly $84,000 l$., of which about $30,000 l$. went to colleges and schools, the re. mainder being spent on lectures or instruction in horticulture, bee keeping, poultry keeping, and various manual processes. Useful as no doubt much of this work is, popular as it is made to be by being spread thinly over a wide area and liberally endowed with prizes, it does little or nothing for the advancement of agriculture, though it may be doing something to make life easier for the cottager. The failure of agricultural instruction that is divorced from any permanent teaching centre may be read in the steady decline in the expenditure for such purposes of the counties which are not connected with any of the institutions subsidised by the Board. There are, indeed, several counties content to spend nothing on agriculture, though their only interests are agricultural; West Sussex, for example, spends not a penny, while several others get through on less than a hundred a year.

When one comes, however, to the second part of the title, "Grants for Agricultural Education and Research," this report makes an indifferent show, since the grants for research only total $355 l$.! Of course, some part of the grants to the colleges is available for research, but if we except the fine work that is being done at Cambridge, there is little going on at the colleges which could come under the category of

No. I 947 , VOL. 75] research. The $355 l$. consists in the main of grants to various institutions carrying out a particular experiment on the improvement of poor pastures, and one sum of $50 l$. to the committee which is working at the improvement of English wheat. Rothamsted still remains without a grant.

Account should also be taken of one or two departmental committees which are inquiring into stock diseases; at present, for example, there is one at work on contagious abortion in cattle, and a former inquiry into "louping ill" in sheep has recently reported-the two costing about 3000 . But compare this expenditure on research with that of the United States Department of Agriculture: from the appropriations for the fiscal year ending June $3^{\circ}$, I905, we extract the following items for investigation work alone, exclusive of the salaries of the permanent officials of the Department.

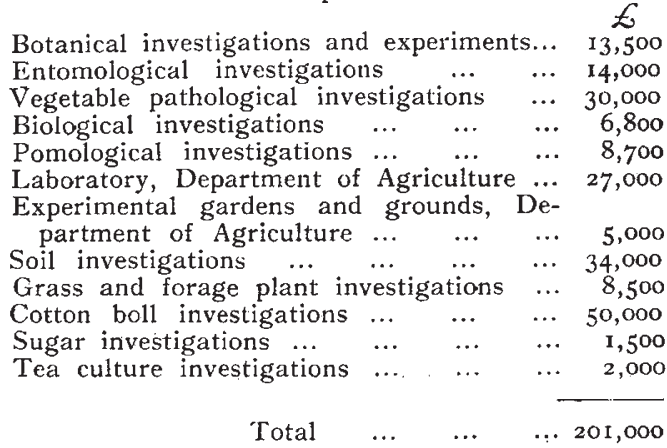

It is the smallness of the Board's contribution to research, the life-blood of scientific education, which led Mr. J. F. Mason, the Member for Windsor, to move an amendment to the address last week to direct attention to the neglect of agricultural research on the part of the Government. Mr. Mason dwelt upon the prime importance of research to farming in this country where intensive farming is carried on and a large monetary return per acre must be obtained. $\mathrm{He}$ instanced the losses that have been occasioned by plant diseases, which could only be dealt with after organised investigation of their causes and origin. He particularly pleaded for assistance to Rothamsted, the one institution for agricultural research of the first rank that this country possesses, but which, deriving its income from private benefactions only, is now handicapped for lack of funds.

The amendment received a sympathetic discussion from members on both sides of the house, and Sir Edward Strachey, for the Board of Agriculture, said "that no one was more anxious than he to see larger sums applied to experiment and research. But scientific investigation had suffered in the past not so much from neglect as frol.1 want of appreciation on the part of the public. If the House had omitted to provide sufficient funds for such investigation, it was because the question had not been brought forward. ... On the other hand, it might very fairly be said that there was a general demand among agriculturists for larger grants from State funds; and the House might rest assured that the President of the Board of Agriculture would make representations to the Treasury as to the general feeling expressed in the debate on that point.'

But now that the question is attracting public attention we trust that the Board of Agriculture will be encouraged to make bolder demands on the Treasury. There was a scheme for creating a council for agricultural research which seems to have fallen 
through for lack of an initial grant; there are also the recommendations of the Roval Commission on fruit-growing, which seem no nearer realisation; as an advisory body the Board of Agriculture must get itself discredited unless it possesses some machinery for investigation.

\section{THE UNIVERSITY OF TORONTO.}

$T \mathrm{HE}$ very generous provision recently made by the province of Ontario for the financial support of the University of Toronto, as well as the very important changes brought about last year in the constitution of the latter, are of more than local interest, and therefore the following account may be of service to those who watch the development of the colonial universities.

This university, which was founded by Royal Charter in 1827 and began teaching in 1843 , had as its original endowment 225 , 000 acres of Crown lands in the province of Upper Canada, now Ontario, and the amount realised from the sale of these lands gave, with the tuition fees, all the revenue the university had until 1897 , when the Legislature granted it 140ol. a year and 132 , ooo acres of wild lands within the unsettled portions of the province. In roo t the Legislature further undertook to pay the annual chargo of the departments of physics, chemistry, and mineralogy and geology. This latter addition to the resources of the university was rendered necessary by the gradual decrease in the revenue from the endowment and by the great increase in the number of students in attendance, taxing the energies of the teaching staff and the accommodation of the classrooms and laboratories to the utmost. Until rao6 the revenues were spent in supporting two faculties, arts and medicine, as the annual budget of the School of Practical Science (engineering and technical science generally) was met directly out of the provincial treasury.

This provision of Igor met the situation for about three years, but in Igo5 the need of additional laboratories and other buildings, as well as the continually increasing numbers of students, made the question of further financial aid a very pressing one. There was also the question of the advisability of changing the relations which hitherto existed between the State and the university. All appointments to the staff had been made by the Lieutenant-Governor-inCouncil, and, though these had been free from political taint, there was the possibility of such being dictated by considerations of party politics. It was also recognised that the constitution of the universitv was very cumbrous and unadapted for the work it had to do.

The urgent aspect of the situation led the newly installed Whitney Administration to appoint a Royal Commission to examine and report upon the constitution of the university and its constituent colleges and faculties. The commission was a very representative one, and from the first it earnestly set about its task, which was recognised to be a difficult one. It visited the larger American universities, conferrer with their presidents and others who could fumish any aid in the form of advice, and patiently heard the views of the staffs of the various colleges and faculties This commission also took up the financial problem of the maintenance of the university.

The results of their labours were presented in the form of a report to the Lieutenant-Governor of the province in March of last year, and at the same time the commission drafted a bill for introduction into the Legislature to embody, in the form of an Act, the changes which were thought advisable in the constitution. The suggested changes practically involved re-casting the constitution. The Act was accepted by both sides of the Legislature, and only minor modifications were made in its passage through the House.

Some of the changes made were sweeping. The control of the university was vested in a board of governors, twenty in number, eighteen appointed by the Crown, one the chancellor, elected by the graduates, and one the president, appointed by the board. This board was given the management of the endowment and income, but it can make no appointment to the teaching staff except on the recommendation of the president, on whom now devolves the responsibility for the staff of the university. By the Act the School of Practical Science was made an integral part of the university, and its finances were made subject to the control of the board of governors.

By far the most important result of the Royal Commission's labours, and which was embodied in the Act of the Legislature, ensures to the university henceforth adequate financial support. The provision to this end consisted in the granting to the university each year one-half of the annual average amount of the revenues derived by the province from succession duties or death duties, the annual average to be based on the receipts of the preceding three years. The total amount of these duties for the years $1903-4-5$ was $304,800 l$., or antulally $101,600 l$. Onehalf of this latter sum has, as the Act directs, been paid to the university for the academic year 1906-7. As the province is growing wealthy rapidly, and consequently these succession duties are annually increasing in amount, of course the sum to be handed over annually by the province to the university will correspondingly increase. The amount to be thus given for the academic year 1907-8 will be $71,000 l$, and it is estimated that the university will receive from this same source in I908-9 about roo,oool. What it will be in a few years more cannot be approximately forecasted, but it is not unlikely that within ten years the death duties may average $300,000 l$., of which the university would receive $\mathrm{x} 5 \mathrm{0}$, oool.

As the ordinary income of the university, apart from that derived from succession duties, and apart also from interest on scholarship funds, is about $44,000 l$., it may be seen that the total income from all sources for I906-7 is $97,400 l$, and for I $907-8$ about in 8 ,oool. but for 1008-9 it will be about $147,000 l$. It is not at all improbable that the income of the university five vears from now may be in the neighbourhood of $\$ I, 000,000$, or more than $200,000 l$.

This is a very large income, but it must be noted that the work that the university has to do is also very great. It has not to undertake instruction in agriculture, for the province already maintains a splendid College of Agricutture at Guelph for which the annual budget is about $30,00 \mathrm{c}$. It has, however, to provide adequately for faculties of arts, medicine, applied science, and education. and the task may be gauged from the fact that there ore already 2700 students in the first three faculties. It has also to do for Canada what the great American universities are doing for the Uniter States, that is, to meet the demand for advanced teaching and for research in all departments. It is, indeed, the ambition of some to develop the university into as great a representative of learning and research as either Harvard or Johns Hopkins is, and to make it at the same time a centre for the intellertual life of the Canadian nation to be: As it is now it is the targest and werlthiest colonial university of the Empire. A. B. Macallum. No. I 947 . VOL. 75$]$ 